\title{
A spatial assessment of stream-flow characteristics and hydrologic alterations, post dam construction in the Manyame catchment, Zimbabwe
}

\author{
Tongayi Mwedzi ${ }^{1 *}$, Loreen Katiyo', Francis T Mugabe', Taurai Bere' ${ }^{1}$, Courage Bangira', Tinotenda Mangadze \\ and Olga L Kupika' \\ ${ }^{1}$ Chinhoyi University of Technology, P Bag 7724, Off Harare/ Chirundu Road, Chinhoyi, Zimbabwe
}

\begin{abstract}
The global hydrologic regime has been intensively altered through activities such as dam construction, water abstraction, and inter-basin transfers. This paper uses the Range of Variability Approach (RVA) and daily stream flow records from nine gauging stations to characterize stream-flow post dam construction in the Manyame catchment, Zimbabwe. We identify which variables continue to be altered, upstream and at different distances downstream, to distinguish sections with the highest potential for ecological disruption and to understand how hydrological alterations dissipate downstream of dams. Our results indicate that different sections of the same river have different stream-flow characteristics post dam construction. The most adverse effects of dams were on downstream stretches of the river which were characterized by low flows, extreme low flows and an increased number of zero-flow days. These differences reflect the operation rules of the Manyame catchment dams. While the change in stream-flow characteristics is apparent in the $0-10 \mathrm{~km}$ range, it is slightly felt in the $11-20 \mathrm{~km}$ range and totally disappears at distances $>20 \mathrm{~km}$ downstream of dams. These changes in stream characteristics, and that damming is only restricted to the upper third of the catchment, make the hydrologic fragmentations in the catchment minor. However, the continued hydrologic alterations post dam construction raise important concerns about the interactions of hydrology with other factors like sediment deposition upstream of dams and climate change. We recommend that catchment managers target enhancing the natural flow variability of the river instead of meeting target flows.
\end{abstract}

Keywords: damming, range of variability approach, stream-flow characteristics

\section{INTRODUCTION}

Flow is the primary driver of physical habitat conditions in rivers, which in turn is a major determinant of biotic composition (Jiang et al., 2014). Water allocated for freshwater ecosystems (environmental flows) must therefore be in the context of the natural variability of the flow regime (Mathews and Richter, 2007). The natural variability of the flow regime is of ecological significance and has been reported to determine the composition, diversity, productivity, and resilience of ecosystems (Smakhtin et al., 2004). Furthermore, lotic organisms which evolved in the context of natural flow regimes may not thrive in new imposed regimes (Pyron and Neumann, 2008). However, the global hydrologic regime has been intensively altered through activities such as dam construction, inter-basin transfers and water abstraction (Pringle et al., 2000; Pyron and Neuman, 2008). Dam construction, for instance, alters important characteristics of the flow regime, i.e., magnitude, frequency, duration, timing (predictability), and the rate of change (flashiness) (Poff et al., 1997; Dudgeon, 2000; Jiang et al., 2014). This results in hydrologic fragmentation (Jiang et al., 2014), habitat fragmentation, conversion of lotic to lentic habitat, degraded water quality, altered sediment transport processes, and changes in timing and duration of floodplain inundation (Pringle et al., 2000). Such changes have an impact on biological communities and the ecological integrity of rivers worldwide (Dudgeon, 2000; Pringle et

\footnotetext{
To whom all correspondence should be addressed.

× +263 773534346; e-mail: mrmwedzi@gmail.com

Received: 29 April 2015; accepted in revised form 15 February 2016
}

al., 2000). As such, many studies (e.g. Poff et al., 1997; Richter et al., 1997; Pringle et al., 2000; Gao et al., 2013; Jiang et al., 2014) have been conducted to investigate and characterize the hydrological consequences of damming. However, many of these studies have used the traditional approach of comparing flow variability before and after dam construction. This is ideal, especially when pre-construction and post-construction data are available.

This is not the case in Zimbabwe, where collection of most of the data for gauges downstream of most dams starts after the dam has been constructed. This should not deter research, however, as it is equally important to understand continued hydrologic changes post dam construction, which only a few studies have looked at. Continued hydrologic alterations post dam construction are very important in a climate change era with growing municipal, industrial and agricultural demands for water (Pegg et al., 2003). Additionally, the spatial patterns of the hydrologic alterations post dam construction are rarely evaluated (Jiang et al., 2014). Notwithstanding, knowledge on how the hydrological effects of damming dissipate within the river system is of importance, as understanding the downstream recovery will be of much help in restoration efforts, which have become popular in recent times. The study of these effects is also of importance in a tropical sub-Saharan African set-up, where such studies are rarely conducted and river restoration issues are yet incipient.

The current study uses the Range of Variability Approach (RVA; Richter et al., 1996; Mathews and Richter, 2007, Yang et al., 2014) to characterize streamflow post dam construction in different sections of the Manyame catchment, Zimbabwe. We identify continued alterations post dam construction, upstream and at different distances downstream of dams, to identify sections with 
the highest potential for ecological disruption and to understand how hydrological alterations dissipate downstream of dams. We hypothesize that streamflow characteristics post dam construction are similar at all sections of the river; upstream and downstream of dams. We also hypothesize that there are continued hydrologic alterations in all sections of the river (downstream or upstream of a dam) post dam construction.

\section{METHODS}

\section{Study area}

The Manyame catchment (Fig. 1) is one of seven major river basins constituting the Zimbabwean hydrological water management system. The catchment has a total estimated area of $40497 \mathrm{~km}^{2}$ (ZINWA, 2014) and is the most urbanized catchment in Zimbabwe, incorporating four administrative provinces, namely, Harare Metropolitan, Mashonaland East, Mashonaland West and Mashonaland Central. The catchment's need for water for municipal, agricultural, industrial and mining purposes is therefore apparent. It is thus characterized by impoundments on the Manyame River main stem and on its tributaries. Our study focused on a subcatchment covering the main stem (Manyame River) and Mukwadzi River (Fig. 1). This area was specifically chosen as it encompasses the most dammed part of the catchment. There are 6 relatively-large dams in this subcatchment, namely, Harava Dam, Seke Dam, Lake Chivero, Manyame Dam (formerly known as Darwendale Dam), Biri Dam and Mazvikadei Dam (Table 1). Five of these large dams are on the Manyame River and only one (Mazvikadei Dam) is on the Mukwadzi River.

We used Zimbabwe National Water Authority (ZINWA) daily streamflow records from nine gauging stations (C2, C104, C3, C17, C61, C75, C74, C64 and C77; Table 2) in the Manyame River catchment. These gauging stations were assigned site numbers (in this study) and are henceforth referred to as Sites 1 to 9 , respectively (Table 2, Fig. 1). Sites 1 and 2 were upstream of dams, while Sites 3-9 were at different distances downstream of dams. According to Pyron and Neumann (2008), sites in the region of $8 \mathrm{~km}$ downstream of a dam could still suffer from hydrological influences of damming. Thus, we chose three different distances to investigate the downstream hydrological influences of dams. Consequently, Sites 3 and 4 were $0-10 \mathrm{~km}$ downstream of dams, Sites 5, 6 and 7 were 11-20 km downstream of dams and Sites 8 and 9 were $>20 \mathrm{~km}$ downstream of dams. There is also a general increase in drainage area as we move from Site 1 to Site 9; the smallest drainage area being $409 \mathrm{~km}^{2}$ at Site 2 and the largest drainage area being $9744 \mathrm{~km}^{2}$ at Site 9 .

\section{TABLE 1}

\begin{tabular}{|c|c|c|c|c|}
\hline $\begin{array}{l}\text { Reservoir } \\
\text { Name }\end{array}$ & $\begin{array}{c}\text { Year } \\
\text { Commissioned }\end{array}$ & $\begin{array}{c}\text { Reservoir } \\
\text { Area } \\
\text { (ha) }\end{array}$ & $\begin{array}{l}\text { Wall } \\
\text { Height } \\
\text { (m) }\end{array}$ & $\begin{array}{c}\text { Volume } \\
\left(\mathrm{m}^{3} \times 10^{6}\right)\end{array}$ \\
\hline Harava & 1973 & 215 & & 9 \\
\hline Seke & 1929 & 109 & & 4 \\
\hline Chivero & 1952 & 2630 & 40 & 250 \\
\hline Manyame & 1976 & 8100 & 28 & 480 \\
\hline Biri & 2000 & 112 & 35 & 172 \\
\hline Mazvikadei & 1988 & 2300 & 63.5 & 360 \\
\hline
\end{tabular}

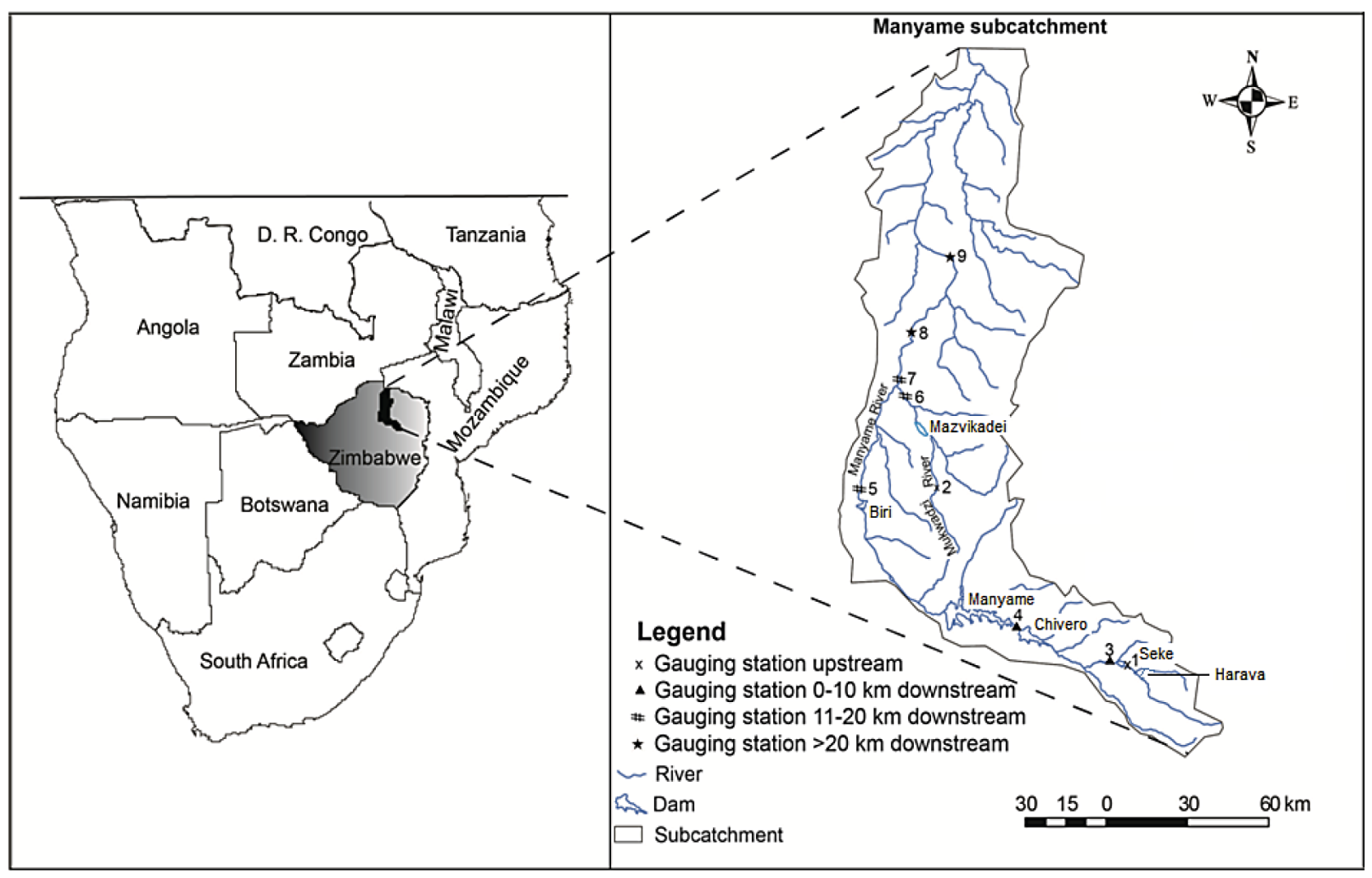

Figure 1

The Manyame catchment gauging stations (marked 1-9) used in this study 
TABLE 2

Detailed information on the streamflow gauging stations

\begin{tabular}{|c|c|c|c|c|c|c|c|}
\hline \multirow{2}{*}{$\begin{array}{l}\begin{array}{l}\text { Site } \\
\text { number }\end{array} \\
1\end{array}$} & \multirow{2}{*}{$\begin{array}{c}\text { Station } \\
\mathrm{C} 2\end{array}$} & \multicolumn{2}{|c|}{ Location } & \multirow{2}{*}{ Upstream dam } & \multirow{2}{*}{$\begin{array}{c}\begin{array}{c}\text { Drainage } \\
\left.\mathbf{( k m}^{\mathbf{2}}\right)\end{array} \\
777\end{array}$} & \multirow{2}{*}{$\begin{array}{c}\begin{array}{c}\text { Data range } \\
\text { (years) }\end{array} \\
1958-2011\end{array}$} & \multirow{2}{*}{$\begin{array}{c}\begin{array}{c}\text { Position } \\
\text { (dam wall) }\end{array} \\
\text { Upstream }\end{array}$} \\
\hline & & $31^{\circ} 07^{\prime} \mathrm{E}$ & $18^{\circ} 00^{\prime} \mathrm{N}$ & & & & \\
\hline 2 & $\mathrm{C} 104$ & $30^{\circ} 29^{\prime} \mathrm{E}$ & $17^{\circ} 23^{\prime} \mathrm{N}$ & & 409 & $1989-2010$ & Upstream \\
\hline 3 & $\mathrm{C} 3$ & $31^{\circ} 04^{\prime} \mathrm{E}$ & $17^{\circ} 59^{\prime} \mathrm{N}$ & Seke & 793 & $1951-2010$ & $0-10 \mathrm{~km}$ \\
\hline 4 & $\mathrm{C} 17$ & $30^{\circ} 46^{\prime} \mathrm{E}$ & $17^{\circ} 53^{\prime} \mathrm{N}$ & Chivero & 2220 & $1953-2008$ & $0-10 \mathrm{~km}$ \\
\hline 5 & C61 & $30^{\circ} 13^{\prime} \mathrm{E}$ & $17^{\circ} 21^{\prime} \mathrm{N}$ & Biri & 5340 & 2001-2013 & $11-20 \mathrm{~km}$ \\
\hline 6 & $\mathrm{C} 75$ & $30^{\circ} 19^{\prime} \mathrm{E}$ & $17^{\circ} 06^{\prime} \mathrm{N}$ & Mazvikadei & 1730 & 1989-2011 & $11-20 \mathrm{~km}$ \\
\hline 7 & $\mathrm{C} 74$ & $30^{\circ} 18^{\prime} \mathrm{E}$ & $17^{\circ} 05^{\prime} \mathrm{N}$ & Mazvikadei + Biri & 6107 & $2001-2013$ & $11-20 \mathrm{~km}$ \\
\hline 8 & $\mathrm{C} 77$ & $31^{\circ} 22^{\prime} \mathrm{E}$ & $16^{\circ} 55^{\prime} \mathrm{N}$ & Mazvikadei + Biri & 8010 & $2001-2013$ & $>20 \mathrm{~km}$ \\
\hline 9 & C64 & $30^{\circ} 29^{\prime} \mathrm{E}$ & $16^{\circ} 40^{\prime} \mathrm{N}$ & Mazvikadei + Biri & 9744 & 2001-2013 & $>20 \mathrm{~km}$ \\
\hline
\end{tabular}

\section{Quantifying streamflow characteristics and hydrologic} alteration

The RVA (Richter et al., 1996; Mathews and Richter, 2007, Yang et al., 2014) and its associated Indicators of Hydrologic Alteration (IHA) software were used to characterize streamflow and detect altered hydrologic variables at different sites post dam construction. This method, which consists of 67 statistical parameters (Appendix 1), was first described by Richter et al. (1996) using 33 different hydrological indices. These indices were termed Indicators of Hydrologic Alteration (Richter et al., 1996) and grouped into 5 categories: magnitude, timing, duration, frequency and rate of change of discharge (King et al, 2008; Tharme, 2003). Thirty-four (34) other parameters were added to the IHA software in 2005 in order to characterize the hydrograph in a manner that is representative of key flow-ecology relationships (Mathews and Richter, 2007). These were termed 'Environmental Flow Components' (EFCs) and consist of five groups of flow, i.e., extreme low flows, low flows, high flow pulses, small floods, and large floods.

The RVA has been used by scientists and water managers worldwide in environmental flow-related studies (Tharme, 2003; Nature Conservancy, 2007; Mathews and Richter, 2007) as it is considered to be holistic (Mathew and Richter, 2007) or ecologically grounded (Tharme, 2003; Smakhtin and Anputhas, 2006) The method has been used to examine and identify the effects of dams (Galat and Lipkin, 2000; Pegg et al., 2003; Magilligan and Nislow, 2005; Singer, 2007; Gao et al., 2013) and land cover (Schoonover et al., 2006), and the potential effects of hydrologic management compared to natural flow conditions (Richter et al., 1997; Shiau and $\mathrm{Wu}, 2004)$. In the majority of cases, the methodology has been used in trend analysis of pre- and post-regulation scenarios, to characterize the flow-related changes experienced by regulated rivers. However, the method can likewise be utilized to perform a trend assessment of more gradual changes in hydrologic conditions, for example, those owing to transformation of a forest to agricultural use, or resulting from environmental and climate change. While less dramatic than the adjustments apparent in the hydrograph after development of a dam, trend assessment can distinguish parameters that have changed over time (Mathews and Richter, 2007). In this instance, the RVA calculates Spearman Rank Correlation coefficients (SRC) for each of the 67 statistical variables to establish whether a variable has changed significantly within a given time span. SRC values range from -1 to 1 with values closer to 1 or -1 indicating a strong positive or negative temporal correlation. Significant regressions with time (derived from the SRC values at $p<0.05$ ) imply that a hydrological variable has changed significantly during that time interval (Pyron and Neumann, 2008). The streamflow characteristics of sites are given as the long-term median of the 67 variables.

IHA version 7.1 software (Mathews and Richter, 2007) was used for this analysis. One-way analysis of variance (oneway ANOVA) was performed using SPSS version 16 to assess how the streamflow characteristics and the number of altered hydrologic variables varied with dam position. Where significant differences were observed, a post-hoc Tukey's Honestly Significant Difference (HSD) test was done to verify which site categories differed. We used correlation coefficients from IHA regression to plot a principal component analysis (PCA) in CANOCO version 5 (Šmilauer and Lepš, 2014). The PCA was used in identifying the hydrological alterations that best characterize the different sites.

\section{RESULTS}

\section{Streamflow characteristics post dam construction}

Of the 67 statistical parameters used to characterise streamflow in this study, significant differences among site category characteristics (long-term means) were only noted for 11 variables (ANOVA, $p<0.05$; Table 3 ). These variables included monthly flows for October, November, December, July, August and September, 90-day minimum, number of zero-flow days, high-pulse duration, extreme-low-flow duration and high-flow timing. Monthly flows for October, November, December, July, August and September and the 90-day minimum were significantly lowest (Tukey's HSD, $p<0.05$ ) at sites situated $0-10 \mathrm{~km}$ downstream of dams, compared to all of the other site categories which did not significantly differ from each other. Zero-flow days, high-pulse duration and extreme-low-flow duration were significantly highest (Tukey's HSD, $p<0.05$ ) at sites situated $0-10 \mathrm{~km}$ downstream of dams compared to all of the other site categories which did not significantly differ from each other. High-flow timing was significantly highest (Tukey's HSD, $p<0.05)$ at sites situated $0-10 \mathrm{~km}$ and those situated 11-20 km downstream of dams compared to all of the other site categories which did not significantly differ from each other. There were no significant differences in any of the other variables across all site categories.

\section{Hydrologic alteration trends post dam construction}

Regression analysis showed that there has been continued alteration of hydrologic variables in the Manyame catchment 
TABLE 3

Streamflow characteristics that significantly differed in different sections of the Manyame catchment according to position from a dam (mean \pm standard deviation)

\begin{tabular}{|c|c|c|c|c|}
\hline \multirow[b]{2}{*}{ Variable } & \multicolumn{4}{|c|}{ Site Category } \\
\hline & Upstream & $\begin{array}{c}\text { 0-10 km } \\
\text { Downstream }\end{array}$ & $\begin{array}{c}11-20 \mathrm{~km} \\
\text { Downstream }\end{array}$ & $\begin{array}{c}>20 \mathrm{~km} \\
\text { Downstream }\end{array}$ \\
\hline \multicolumn{5}{|c|}{ Magnitude of monthly water conditions $\left(\mathrm{m}^{2}\right)$} \\
\hline October & $0.3 \pm 0.18$ & $0.0 \pm 0.00^{\mathrm{a}}$ & $0.49 \pm 0.2$ & $0.53 \pm 0.1$ \\
\hline November & $0.33 \pm 0.21$ & $0.0 \pm 0.00^{\mathrm{a}}$ & $0.51 \pm 0.2$ & $0.61 \pm 0.2$ \\
\hline December & $0.40 \pm 0.25$ & $0.01 \pm 0.0^{\mathrm{a}}$ & $1.09 \pm 0.5$ & $3.04 \pm 2.3$ \\
\hline July & $0.36 \pm 0.19$ & $0.01 \pm 0.0^{\mathrm{a}}$ & $0.64 \pm 0.3$ & $0.42 \pm 0.0$ \\
\hline August & $0.31 \pm 0.19$ & $0.0 \pm 0.00^{\mathrm{a}}$ & $0.55 \pm 0.2$ & $0.35 \pm 0.1$ \\
\hline September & $0.33 \pm 0.2$ & $0.0 \pm 0.00^{\mathrm{a}}$ & $0.54 \pm 0.2$ & $0.44 \pm 0.2$ \\
\hline \multicolumn{5}{|c|}{ Magnitude $\left(\mathrm{m}^{3}\right)$ and duration of annual extreme water conditions } \\
\hline 90-day minumum & $0.37 \pm 0.15$ & $0.0 \pm 0.00^{\mathrm{a}}$ & $0.52 \pm 0.2$ & $0.39 \pm 0.1$ \\
\hline Number of zero-flow days & $0.0 \pm 0.0$ & $139 \pm 81^{\mathrm{a}}$ & $1.33 \pm 2.3$ & $2.00 \pm 2.83$ \\
\hline High-pulse duration & $6.38 \pm 2.3$ & $13.8 \pm 0.7^{\mathrm{a}}$ & $4.25 \pm 0.4$ & $4.5 \pm 0.7$ \\
\hline \multicolumn{5}{|l|}{ Extreme low flows } \\
\hline Extreme-low-flow duration & $5.0 \pm 2.83$ & $76.3 \pm 93^{\mathrm{a}}$ & $5.58 \pm 1.4$ & $5.5 \pm 2.12$ \\
\hline \multicolumn{5}{|l|}{ High-flow pulses } \\
\hline High-flow timimg & $22.75 \pm 2.47$ & $96.4 \pm 11^{\mathrm{a}}$ & $90 \pm 113^{\mathrm{a}}$ & $14.38 \pm 9$ \\
\hline
\end{tabular}

Superscript values indicate values that are significantly different within the same row (Tukey's HSD, $\mathrm{p}<0.05$ ).

post dam construction (Table 4). Only IHA Group 3 variables (timing of annual extreme water conditions) remained unaltered. Sites with significant hydrologic alterations in IHA Group 1 (magnitude of monthly water conditions) had increased early summer (September - November) flows upstream of dams while the same was not significantly altered in all of the other site categories. The winter flows (June to August) decreased at $0-10 \mathrm{~km}$ distances downstream of dams and did not significantly change in all the other site categories. Altered IHA Group 2 variables (magnitude and duration of annual extreme water conditions) resulted in increases in 1-day, 3-day, 7-day and 30-day minimum flows at upstream sites and at sites located $>20 \mathrm{~km}$ downstream of dams, but the 7-day and 30-day minimum flows decreased at $0-10 \mathrm{~km}$ distances downstream of dams. There was also a significant increase in the number of zero-flow days in the $0-10 \mathrm{~km}$ distance downstream of dams, while the same remained unchanged $11-20 \mathrm{~km}$ downstream of dams, and decreased upstream and at sites situated $>20 \mathrm{~km}$ downstream of dams. The base flow index increased upstream of dams and remained unchanged in all of the other site categories. The variables in IHA Group 4 (frequency and duration of high and low pulses) that were significantly altered resulted in an increased number of low pulses at sites situated 11-20 $\mathrm{km}$ downstream of dams while the same did not change for all of the other site categories. The number of high pulses on the other hand decreased $0-10 \mathrm{~km}$ downstream of dams and remained unchanged for the other site categories. Alteration in IHA Group 5 variables (rate and frequency of water condition changes) led to a decrease in the number of reversals in the sites situated $0-10 \mathrm{~km}$ downstream of dams and remained unchanged for all of the other site categories.

For the EFCs, there was a decrease in the December low flows at sites located 11-20 km downstream of dams and increases in October and November low flows at upstream sites. The other site categories remained unchanged. July low flows decreased $0-10 \mathrm{~km}$ downstream of dams and remained unchanged for all of the other site categories. Extreme-lowflow frequencies decreased at upstream sites and remained unchanged for all of the other site categories. Small-flood timing was only altered at distances $>20 \mathrm{~km}$ downstream of dams, where they occurred at a later date than previously. This site category ( $>20 \mathrm{~km}$ downstream of dams) also experienced a significant increase in small-flood rise rate and a decrease in small-flood fall rate. Alteration of large-flood EFCs led to changes in large-flood timing at sites situated $0-10 \mathrm{~km}$ downstream of dams. The large floods arrived later than usual and there was a decrease in large-flood duration. There was also a decrease in the large-flood duration and large-flood fall rate in the $11-20 \mathrm{~km}$ distance downstream of dams.

\section{Multivariate analysis}

The first four PCA axes accounted for $84.33 \%$ of the total variation. The first and second axes accounted for $66.59 \%$ (Fig. 2) of the total variation, explaining $34.41 \%$ and $32.18 \%$, respectively. Site categories were clearly distinguished by Axes 1 and 2. All of the variables that had small regression values (that are closer to zero - basically unaltered) were negatively associated with Axes 1 and 2, clustering in the first quadrant (top left hand side) of the PCA. These variables were associated with sites located at $>20 \mathrm{~km}$ distances downstream of dams (Sites 8 and 9). Sites located 0-10 km (Sites 3 and 4) and 11-20 km (Sites 5, 6 and 7) downstream of dams loaded positively on Axis 2, being easily distinguished by 18 variables. They were characterized by alterations in zero-flow days, low-pulse duration, extreme-low-flow duration, smallflood rise rate, large-flood timing, rise rate, extreme-low-flow frequency, high-flow timing, small-flood frequency, extremelarge-flood peak, large-flood rise rate, number of low pulses, 
TABLE 4

IHA regression results: Spearman rank correlation coefficients for hydrological variables at sites in Manyame Catchment (only showing variables with at least one significant regression in the same row)

\begin{tabular}{|c|c|c|c|c|}
\hline \multirow[b]{2}{*}{ Variable } & \multicolumn{4}{|c|}{ Site Category } \\
\hline & Upstream & $\begin{array}{c}\text { 0-10 km } \\
\text { Downstream }\end{array}$ & $\begin{array}{c}11-20 \mathrm{~km} \\
\text { Downstream }\end{array}$ & $\begin{array}{c}>20 \mathrm{~km} \\
\text { Downstream }\end{array}$ \\
\hline \multicolumn{5}{|c|}{ Magnitude of monthly water conditions } \\
\hline October & $0.72 *$ & -0.32 & -0.31 & 0.18 \\
\hline November & $0.57^{*}$ & -0.38 & -0.31 & 0.19 \\
\hline July & 0.05 & $-0.5^{*}$ & -0.38 & 0.33 \\
\hline September & $0.45^{*}$ & -0.18 & -0.23 & 0.20 \\
\hline \multicolumn{5}{|c|}{ Magnitude and duration of annual extreme water conditions } \\
\hline 1-day minimum & $0.45^{*}$ & -0.41 & -0.29 & $0.45^{*}$ \\
\hline 3-day minimum & $0.46^{*}$ & -0.43 & -0.33 & $0.47 *$ \\
\hline 7-day minimum & $0.49 *$ & $-0.5^{*}$ & -0.36 & $0.45^{*}$ \\
\hline 30-day minimum & $0.55^{*}$ & $-0.5^{*}$ & -0.35 & $0.45^{*}$ \\
\hline 90-day minimum & 0.30 & -0.41 & $-0.45^{*}$ & 0.36 \\
\hline Number of zero-flow days & $-0.56^{*}$ & $0.8^{*}$ & 0.07 & $-0.46^{*}$ \\
\hline Base flow index & 0.49 & -0.3 & 0.16 & 0.29 \\
\hline \multicolumn{5}{|c|}{ Frequency and duration of high and low pulses } \\
\hline Number of low pulses & -0.03 & 0 & $0.55^{*}$ & -0.08 \\
\hline Number of high pulses & -0.12 & $-0.5^{*}$ & -0.23 & 0.06 \\
\hline \multicolumn{5}{|c|}{ Rate and frequency of water condition changes } \\
\hline Number of reversals & -0.35 & $-0.6^{*}$ & -0.17 & -0.02 \\
\hline \multicolumn{5}{|l|}{ Monthly low flows } \\
\hline October low flow & $0.56^{*}$ & 0.16 & -0.30 & -0.29 \\
\hline November low flow & $0.45^{*}$ & 0.26 & -0.35 & -0.01 \\
\hline December low flow & 0.10 & 0.06 & $-0.51^{*}$ & 0.24 \\
\hline March low flow & 0.13 & -0.28 & -0.16 & $0.45^{*}$ \\
\hline July low flow & 0.10 & -0.34 & -0.41 & 0.43 \\
\hline \multicolumn{5}{|l|}{ Extreme low flows } \\
\hline Extreme low-flow frequency & $-0.47 *$ & 0.34 & 0.40 & -0.12 \\
\hline \multicolumn{5}{|l|}{ Small floods } \\
\hline Small-flood timimg & -0.09 & -0.04 & -0.11 & $0.56^{*}$ \\
\hline Small-flood rise rate & 0.06 & 0.33 & 0.21 & $0.46^{*}$ \\
\hline Small-flood fall rate & -0.1 & -0.17 & -0.22 & $-0.53^{*}$ \\
\hline \multicolumn{5}{|l|}{ Large floods } \\
\hline Large-flood duration & 0 & -0.29 & $-0.56^{*}$ & 0 \\
\hline Large-flood timing & 0 & $0.7^{*}$ & -0.20 & 0 \\
\hline Large-flood fall rate & 0 & -0.42 & $-0.62 *$ & 0 \\
\hline
\end{tabular}

${ }^{*}$ indicates significant regressions with time at $\mathrm{p}<0.05$

high-flood rise rate, Julian date of minimum flow and largeflood peaks. The rest of the variables were positively associated with upstream sites (Sites 1 and 2) and sites located at $>20 \mathrm{~km}$ distances downstream of dams on Axis 2. Axis 1 further distinguished the upstream sites from sites located at $>20 \mathrm{~km}$ distances downstream of dams. The upstream sites loaded negatively on Axis 1 and Axis 2, being characterized by increased February, March, April and August flows; increased August, September, October and November low flows; and increased large-flood frequency, high-flow peaks, high-flow fall rate, high-flow duration, small-flood duration and 30-day maximum flows. The PCA therefore shows a gradient of different hydrological alterations. Upstream sites, sites located $0-10 \mathrm{~km}$ downstream of dams and sites located $11-20 \mathrm{~km}$ downstream of dams were characterized by different kinds of hydrological alterations while sites located $>20$ $\mathrm{km}$ downstream of dams were characterized by variables that were not significantly altered. 


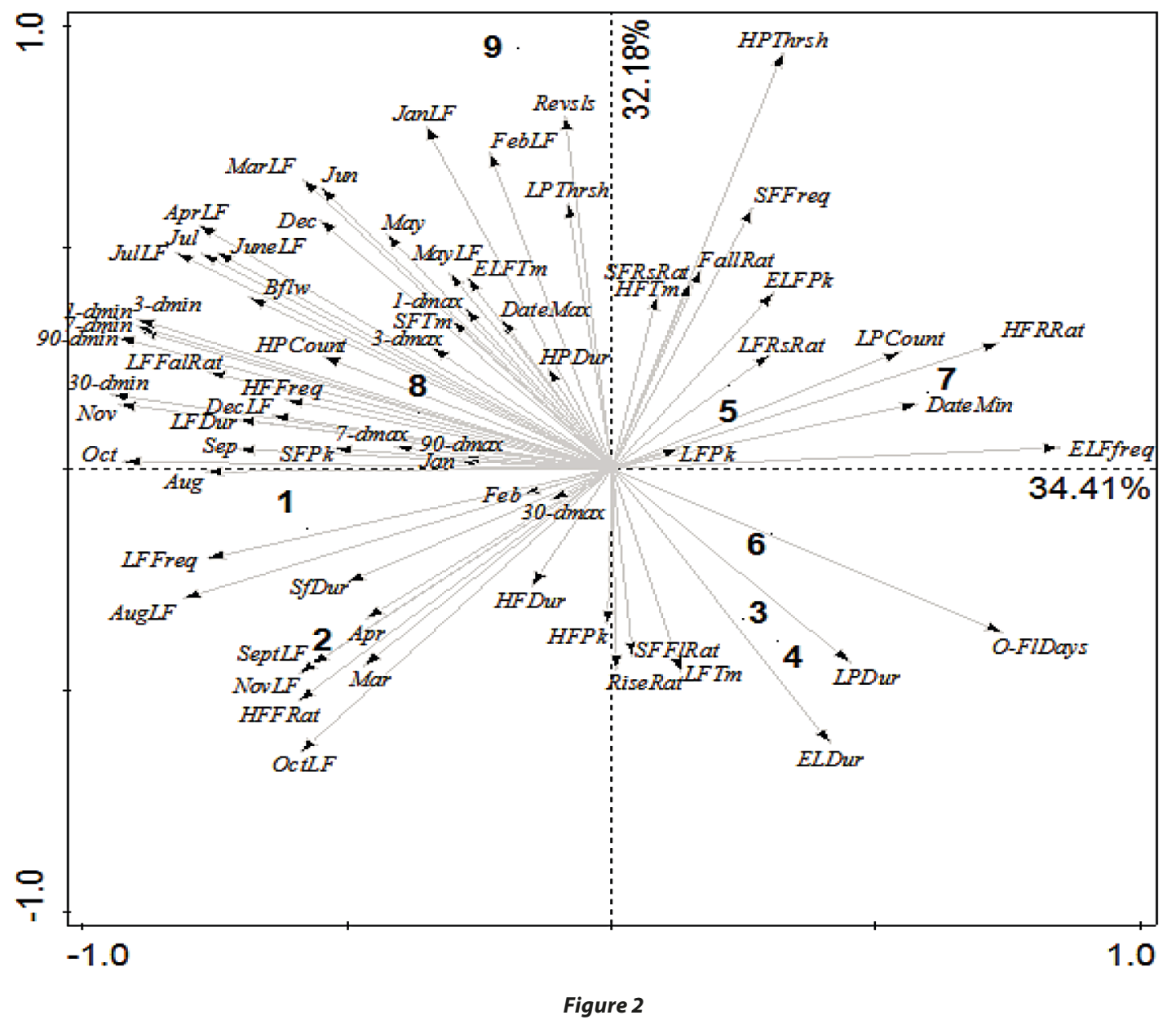

PCA relating hydrological variables to different sites (labelled as Sites 1-9) in the Manyame catchment. Acronyms are given in full in Appendix 1.

\section{DISCUSSION}

\section{Stream-flow characteristics post dam construction}

Our results indicate that different river sections have different streamflow characteristics post dam construction. The streamflow characteristics are especially different in the first $10 \mathrm{~km}$ downstream of a dam while the upstream and further downstream sections are not different. These differences are strongly pronounced in the second half of the year July to December, which have significantly reduced flows in downstream sections $0-10 \mathrm{~km}$ downstream from dams compared to other sections. We reported increased zero-flow days, high-pulse duration, high-flow timing and extreme-low-flow duration at sites situated $0-10 \mathrm{~km}$ downstream of dams compared to other site categories. These findings are typical of river flow after dam construction. Yang et al. (2008) reported decreased median of monthly flows, decreased medians of annual 1-, 3-, 7-, 30-, and 90-day minimum and maximum flows, higher low pulse and high pulse counts, and decreased medians of fall rate, rise rate, and number of reversals in the post-damming period of the Yellow River, China. However this was in comparison with the pre-dam construction period - hence the increased number of altered variables on their studies. The consistent trend in the affected stream-flow characteristics is that the main changes include significant decline of high flows and increase of low flows. These kinds of changes (significantly reduced flows) in streamflow characteristics are known to have adverse effects on biodiversity and the persistence of viable wetlands (Donders et al., 2005; Yang et al., 2008).

Although all of the different sections of a dammed river have potential for ecological disruption, downstream sites located $0-10 \mathrm{~km}$ from the dam wall are the most vulnerable. These differences reflect the operation rules of the Manyame catchment dams. Manyame catchment dams typically store water in winter (May-July) and only release it on demand from downstream farmers and as minimum flows. Flow therefore becomes erratic from July onwards giving rise to different streamflow characteristics at upstream and downstream sections. Water is not released from the dams until the middle of the rainy season (January-February) when the dams are full or almost full. River flow characteristics therefore become similar at all sections from January through to June. This set up meets the requirements of Zimbabwean law which stipulates that a catchment plan must prescribe the minimum amount of water set aside for the environment (Zimbabwe, 1998). However, this approach falls short of an elementary scientific principle; the integrity of lotic systems depends on their natural variability (Poff et al., 1997). Management must therefore target enhancing the natural flow variability of the river instead of meeting target flows. However, with the rapidly growing human populations and increased water consumption and energy demands it is almost impossible to restore the river's natural variability. Despite this challenge, management must consider developing new reservoir management schemes without significantly affecting the main purposes of the dams (Jiang et al., 2014). 
Multivariate analysis indicates that while this change in hydrology is strong and apparent in the $0-10 \mathrm{~km}$ range, it is slightly felt in the 11-20 km range and totally disappears at distances $>20 \mathrm{~km}$ downstream of dams. Dam induced hydrologic fragmentation in the Manyame catchment therefore resulted in different sections of the river being dominated by different flow regimes. However, the fragmentations in the Manyame catchment are minor as they are restricted mainly to the upper sections of the catchment and totally disappear at distances greater than $20 \mathrm{~km}$. By definition, a river is considered to be severely fragmented when only less than a quarter of its main channel does not have a dam and the stream-flow pattern has changed substantially (Revenga et al., 2000). This is not the case with the Manyame catchment where more than half of the catchment still remains undammed and flow has not been substantially changed on many sections.

\section{Hydrologic alteration trends post dam construction}

Our results indicate that the flow regime at different sections of the Manyame catchment has been altered over the past 49 years post dam construction. Flow alteration has been reported to be ubiquitous the world over (Pyron and Neumann, 2008) and research has attributed this to the widespread construction of dams (Pringle et al., 2000; Magilligan and Nislow, 2005; Pyron and Neumann, 2008). However, it is clear from our study that hydrological alterations have continued to occur in all sections of the river post dam construction. The observed alterations raise concerns about possible interactions of dam influence and climate change. Many studies have managed to show that streamflow variations were correlated with the spatial and temporal distribution of precipitation (Alberts et al., 2004; Gao et al., 2013). Yang et al. (2008) argues that it is almost impossible to differentiate individual roles of climate change and human activities in hydrological alterations as complicated climatic changes also have the potential to affect the flow regimes. It is therefore necessary to quantify the possible impacts of climate change on hydrological alterations in ongoing research. It is also important that the consequential ecological damages of such changes are quantified as they are not extensively understood (Pyron and Neumann, 2008).

\section{Multivariate analysis: identifying hydrologic alterations associated with different sections of the river depending on dam position}

While the streamflow characteristics have been altered in the Manyame catchment, the altered variables are different in different sections of the catchment. PCA results showed a gradient of alteration indicating the influence of the presence, position or distance from the dam. Sites located at $>20 \mathrm{~km}$ distances downstream of dams had the least alteration compared to other site categories. This concurs with findings by other authors who reported that the downstream effects of dams decreased as distance from the dam increased (Richter et al., 1998; Galat and Lipkin, 2000; Batalla et al., 2004; Jiang et al., 2014). At such great distances the influence of the dam on the flow regime is reduced. Batalla et al. (2004) attributed this behaviour to increasing drainage area while Galat and Lipkin, (2000) found that the effects of hydrologic alteration dissipate below tributary junctions. The drainage area at distances $>20 \mathrm{~km}$ in our study was comparatively larger than the area at distances $0-10$ $\mathrm{km}$ and 11-20 km downstream of dams and hence we are able to attribute the attenuated effects of damming to the drainage area and influence of tributaries. Batalla et al. (2004) reported recovery to occur after tens of kilometers and doubling of drainage area in the Najerilla and the Arago rivers in Spain. The flow regime at such sites is therefore being determined by other streams and not only by the dammed site. Tributaries have been reported to play an important role in characterizing the downstream hydrological and chemical characteristics of water as they 'dilute' the effects of damming and other disturbances upstream (Katano et al., 2009; Jiang et al., 2014).

Little is usually mentioned about the upstream hydrologic impacts of dams as the focus is usually downstream. However it is clear from our study that the dam not only has an impact downstream but upstream as well. The variables that continue to be altered upstream of a dam post construction include September, October and November flows; 1-day, 3-day, 7-day and 30-day dam minimum flows; number of zero-flow days, base-flow index; October and November low flows and extremelow-flows frequency. The continued change in these flows can be attributed to the backflow from the dam which renders particular sections of the river lentic as well. This transformation from a lotic to a lentic system is bound to have ecological impacts as organisms that are adapted to lotic systems suddenly have to adapt to a lentic system. The continued hydrologic alteration and increase in these variables can be attributed to a decreasing dam storage capacity caused by sediment deposition, as reported by Yang et al. (2008) on the Yellow River, China.

\section{CONCLUSION}

Stream-flow characteristics at different sections in the Manyame catchment are dependent on the presence, position and distance from the dam. Manyame catchment is therefore hydrologically fragmented with the streamflow characteristics upstream of dams being different to those immediately downstream of dams. The extent of fragmentation in the catchment is however minor as the greater part of the rivers remain free-flowing and the downstream impacts are only limited to the first $20 \mathrm{~km}$, after which the downstream effects of the dams are diminished. However, hydrologic alteration has continued to persist in the Manyame catchment post dam construction. The main changes entail a continued replacement of high flows, floods and minimum flows by extreme low flows and an increased number of zero-flow days at downstream sites. Upstream changes entail a continued alteration and increase in high flows. These continued changes to the flow regime raise important concerns about the interactions of hydrology with other factors like sediment deposition upstream of dams and climate change. We recommend that catchment managers aim to enhance the natural flow variability of the river instead of meeting target flows.

\section{ACKNOWLEDGEMENTS}

This study was made possible by the provision of funds from Chinhoyi University of Technology: Research grant Ref no. SERC 07/13/11.

\section{REFERENCES}

ALBERTS HC, ALBERTS RM, BLOOM MF, LAFLAMME AD and TEERIKANGAS S (2004) The three Gorges dam project from a systems viewpoint. Syst. Res. Behav. Sci. 21 585-602. http://dx.doi. org/10.1002/sres.604

BATALLA RJ, GOMEZ CM and KONDOLF GM (2004) Reservoirinduced hydrological changes in the Ebro River basin (NE Spain). J. Hydrol. 290 117-136. http://dx.doi.org/10.1016/j. jhydrol.2003.12.002 
DONDERS TH, FRIEDERIKE W and HENK V (2005) Quantification strategies for human-induced and natural hydrological changes in wetland vegetation, southern Florida, USA. Q. Res. 64 (3) 333-342. http://dx.doi.org/10.1016/j.yqres.2005.08.016

DUDGEON D (2000) Large-scale hydrological changes in tropical Asia: prospects for riverine diversity. BioScience 50 793-806. http:// dx.doi.org/10.1641/0006-3568(2000)050[0793:LSHCIT]2.0.CO;2

GALAT DL and LIPKIN RL (2000) Restoring ecological integrity of great rivers: historical hydrographs aid in defining reference conditions for the Missouri River. Hydrobiologia 422/423 29-48. http:// dx.doi.org/10.1023/A:1017052319056

GAO B, YANG D and YANG H (2013) Impact of the Three Gorges Dam on flow regime in the middle and lower Yangtze River. Q. Int. 304 43-50. http://dx.doi.org/10.1016/j.quaint.2012.11.023

JIANG L, BAN X, WANG X and CAI X (2014) Assessment of hydrologic alterations caused by the Three Gorges dam in the middle and lower reaches of Yangtze River, China. Water 2014 (6) 1419-1434. http://dx.doi.org/10.3390/w6051419

KATANO I, JUNJIRO N, NEGISHI JN, MINAGAWA T, DOI H, KAWAGUCHI Y and KAYABA Y (2009) Longitudinal macroinvertebrate organization over contrasting discontinuities: effects of a dam and a tributary. J. N. Am. Benthol. Soc. 28 (2) 331-351. http:// dx.doi.org/10.1899/08-010.1

KING JM, THARME RE and DE VILLIERS MS (eds) (2008) Environmental flow assessments for Rivers: Manual for the building block methodology (updated edition). WRC Report No TT 354/08. Water Research Commission, Pretoria.

MAGILLIGAN FJ and NISLOW KH (2005) Changes in hydrologic regime by dams. Geomorphology 71 61-68. http://dx.doi. org/10.1016/j.geomorph.2004.08.017

MATHEWS R and RICHTER BD (2007) Application of the indicators of hydrologic alteration software in environmental flow setting. J. Am. Water Resour. Assoc. 43 (6) 1400-1413. http://dx.doi. org/10.1111/j.1752-1688.2007.00099.x

NATURE CONSERVANCY (2009) Indicators of Hydrologic Alteration Version 7.1: User's Manual. The Nature Conservancy, Charlottesville, Virginia.

PEGG MA, PIERCE CL and ROY A (2003) Hydrological alteration along the Missouri River basin: a time series approach. Aquat. Sci. 65 63-72. http://dx.doi.org/10.1007/s000270300005

POFF NL, ALLAN JD, BAIN MB, KARR JR, PRESTEGAARD KL, RICHTER BD, SPARKS RE and STROMBERG JC (1997) The natural flow regime: a paradigm for river conservation and restoration. BioScience 47 769-784. http://dx.doi.org/10.2307/1313099

PRINGLE CM, FREEMAN MC and FREEMAN BJ (2000) Regional effects of hydrologic alterations on riverine macrobiota in the New World: tropical-temperate comparisons. Bioscience 50 807-823. http://dx.doi. org/10.1641/0006-3568(2000)050[0807:REOHAO]2.0.CO;2

PYRON M and NEUMANN K (2008) Hydrologic alterations in the Wabash River watershed, USA. River Res. Appl. 24 1175-1184. http://dx.doi.org/10.1002/rra.1155
REVENGA C, BRUNNER J, HENNINGER N, KASSEM K and PAYNE R (2000) Pilot Analysis of Global Ecosystems: Freshwater System. World Resources Institute, Washington DC.

RICHTER BD, BAUMGARTNER JV, BRAUN DP and POWELL J (1998) A spatial assessment of hydrologic alteration within a river network. Regul. rivers 14 329-340. http://dx.doi.org/10.1002/ (SICI)1099-1646(199807/08)14:4<329::AID-RRR505>3.0.CO;2-E

RICHTER BD, BAUMGARTNER JV, POWELL J and BRAUN DP (1996) A method for assessing hydrologic alteration within ecosystems. Conserv. Biol 10 1163-1174. http://dx.doi. org/10.1046/j.1523-1739.1996.10041163.x

RICHTER BD, BAUMGARTNER JV, WIGINGTON R and BRAUN DP (1997) How much water does a river need? Freshwater Biol 37 231-249. http://dx.doi.org/10.1046/j.1365-2427.1997.00153.x

SCHOONOVER JE, LOCKABY BG and HELMS BS (2006) Impacts of land cover on stream hydrology in the West Georgia Piedmont, USA. J. Environ. Qual. 35 2123-2131. http://dx.doi.org/10.2134/jeq2006.0113

SHIAU JT and WU FC (2004) Assessment of hydrologic alterations caused by Chi-Chi diversion weir in Chou-Shui Creek, Taiwan: opportunities for restoring natural flow conditions. River Res. Applic. 20 401-412. http://dx.doi.org/10.1002/rra.762

SINGER MB (2007) The influence of major dams on hydrology through the drainage network of the Sacramento River basin, California. River Res. Applic. 23 55-72. http://dx.doi.org/10.1002/ rra.968

SMAKHTIN V and ANPUTHAS M (2006) An assessment of environmental flow requirements of Indian River basins. International Water Management Institute Research Report 107. International Water Management Institute, Colombo.

SMAKHTIN V, REVENGA C and DÖLL P (2004) A pilot global assessment of environmental water requirements and scarcity. Water Int. 29 (3) 307-317. http://dx.doi. org/10.1080/02508060408691785

ŠMILAUER P and LEPŠ J (2014) Multivariate Analysis of Ecological Data using Canoco 5. Cambridge University Press, Cambridge. http://dx.doi.org/10.1017/CBO9781139627061

THARME RE (2003) A global perspective on environmental flow assessment: emerging trends in the development and application of environmental flow methodologies for Rivers. River Res. Appl. 19 397-441. http://dx.doi.org/10.1002/rra.736

YANG P, YIN X, YANG Z and TANG J (2014) A revised Range of Variability Approach considering the periodicity of hydrological indicators. Hydrol. Process. 28 (26) 6222-6235. http://dx.doi. org/10.1002/hyp.10106

YANG T, ZHANG Q, CHEN YD, TAO X, XU C and CHEN X (2008) A spatial assessment of hydrologic alteration caused by dam construction in the middle and lower Yellow River, China. Hydrol. Processes 22 3829-3843. http://dx.doi.org/10.1002/hyp.6993 ZIMBABWE (1998) Water Act. Government Printers, Harare. ZINWA (2014) Zimbabwe National Water Authority. URL: http:// www.zinwa.co.zw/htm/dams.htm (Accessed 5 March 2014). 
TABLE A1

The 67 Range of Variability Approach (RVA) variables with acronyms used in Fig. 2.

\begin{tabular}{l|l} 
RVA variable & Acronym used in Fig. 2
\end{tabular}

Indicators of Hydrologic Alteration (IHA) variables

Group 1 - Magnitiude of monthly water conditions

\begin{tabular}{|l|c|}
\hline October & Oct \\
\hline November & Nov \\
\hline December & Dec \\
\hline January & Jan \\
\hline February & Feb \\
\hline March & Mar \\
\hline April & Apr \\
\hline May & May \\
\hline June & Jun \\
\hline July & Jul \\
\hline August & Aug \\
\hline September & Sep \\
\hline
\end{tabular}

Group 2 - Magnitiude and duration of annual extreme water conditions

\begin{tabular}{l|l} 
3-day minimum & 3-dmin
\end{tabular}

\begin{tabular}{l|l} 
7-day minimum & 7-dmin
\end{tabular}

\begin{tabular}{l|l} 
30-day minimum & 30 -dmin
\end{tabular}

\begin{tabular}{l|l} 
90-day minimum & 90-dmin
\end{tabular}

\begin{tabular}{l|l} 
1-day maximum & 1 -dmax
\end{tabular}

\begin{tabular}{l|l} 
3-day maximum & 3-dmax
\end{tabular}

\begin{tabular}{l|l} 
7-day maximum & 7-dmax
\end{tabular}

\begin{tabular}{l|l} 
30-day maximum & 30-dmax
\end{tabular}

\begin{tabular}{l|l} 
90-day maximum & $90-d \max$
\end{tabular}

Number of zero-flow days $\quad$ O-

\begin{tabular}{l|l} 
Base-flow index $\quad$ Bflw
\end{tabular}

Group 3 - Timing of annual extreme water conditions

\begin{tabular}{|l|l}
\hline Date of minimum & DateMin
\end{tabular}

\begin{tabular}{|l|l}
\hline Date of maximum & DateMax
\end{tabular}

Group 4 - Frequency and duration of high and low pulses

\begin{tabular}{|l|c|}
\hline Number of low pulses & LPCount \\
\hline Low-pulse duration & LPDur \\
\hline Number of high pulses & HPCount \\
\hline High-pulse duration & HPDur \\
\hline Group 5- Rate and frequency of water condition changes \\
\hline Rise rate & RiseRat \\
\hline Fall rate & FallRat \\
\hline Number of reversals & Revsls \\
\hline
\end{tabular}

\begin{tabular}{|c|c|}
\hline \multicolumn{2}{|c|}{ Table A1 (continued) } \\
\hline RVA variable & Acronym used in Fig. 2 \\
\hline \multicolumn{2}{|c|}{ Environmental Flow Component (EFC) variables } \\
\hline \multicolumn{2}{|l|}{ Monthly low flows } \\
\hline October low flow & OctLF \\
\hline November low flow & NovLF \\
\hline December low flow & DecLF \\
\hline January low flow & JanLF \\
\hline February low flow & FebLF \\
\hline March low flow & MarLF \\
\hline April low flow & AprLF \\
\hline May low flow & MayLF \\
\hline June low flow & JuneLF \\
\hline July low flow & JulLF \\
\hline August low flow & AugLF \\
\hline September low flow & SeptLF \\
\hline \multicolumn{2}{|l|}{ Extreme low flows } \\
\hline Extreme-low-flow peak & ELFPk \\
\hline Extreme-low-flow duration & ELDur \\
\hline Extreme-low-flow timing & ELFTm \\
\hline Extreme-low-flow frequency & ELFfreq \\
\hline \multicolumn{2}{|l|}{ High flow pulses } \\
\hline High-flow peak & HFPk \\
\hline High-flow duration & HFDur \\
\hline High-flow timimg & HFTm \\
\hline High-flow frequency & HFFreq \\
\hline High-flow rise rate & HFRRat \\
\hline High-flow fall rate & HFFRat \\
\hline \multicolumn{2}{|l|}{ Small floods } \\
\hline Small-flood peak & SFPk \\
\hline Small-flood duration & SfDur \\
\hline Small-flood timimg & SFTm \\
\hline Small-flood frequency & SFFreq \\
\hline Small-flood rise rate & SFRsRat \\
\hline Small-flood fall rate & SFFlRat \\
\hline \multicolumn{2}{|l|}{ Large floods } \\
\hline Large-flood peak & SFPk \\
\hline Large-flood duration & SfDur \\
\hline Large-flood timimg & SFTm \\
\hline Large-flood frequency & SFFreq \\
\hline Large-flood rise rate & SFRsRat \\
\hline Large-flood fall rate & SFFlRat \\
\hline
\end{tabular}

